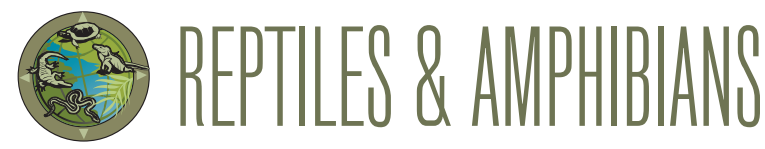

\title{
Comments on a Disputed Record of the Ringed Treeboa, Corallus annulatus (Cope 1875) (Squamata: Boidae), from Northwestern Honduras
}

\author{
José Mario Solis ${ }^{1,2,3}$, Mario Roberto Espinal ${ }^{4}$, Louis W. Porras5 ${ }^{5}$, and José M. Mora ${ }^{6,7}$ \\ ${ }^{1}$ Escuela de Biología, Facultad de Ciencias, Universidad Nacional Autónoma de Honduras, Departamento de Francisco Morazán, Tegucigalpa, Honduras \\ ${ }^{2}$ Grupo de Investigación de Reptiles y Anfibios de Honduras (GIRAH) \\ ${ }^{3}$ Red Mesoamericana y del Caribe para la Conservación de Anfibios y Reptiles (MesoHERP) \\ ${ }^{4}$ Centro Zamorano de Biodiversidad, Escuela Agrícola Panamericana, Zamorano, Departamento de Francisco Morazán, Honduras \\ 57705 Wyatt Earp Avenue, Eagle Mountain, Utah 84005, USA \\ ${ }^{6}$ Unidad de Ciencias Básicas, Sede Atenas y Carrera de Gestión Ecoturística, Sede Central, Universidad Técnica Nacional, Costa Rica \\ (josemora07@gmail.com [corresponding author]) \\ Department of Biology and Museum of Vertebrate Biology, Portland State University, Portland, Oregon 97207, USA (jomora@pdx.edu)
}

R eptiles are among the most remarkable components Kof global biodiversity (Pincheira-Donoso et al. 2013).
Consequently, knowledge of their distribution is fundamental for understanding aspects of their ecology and biogeography,

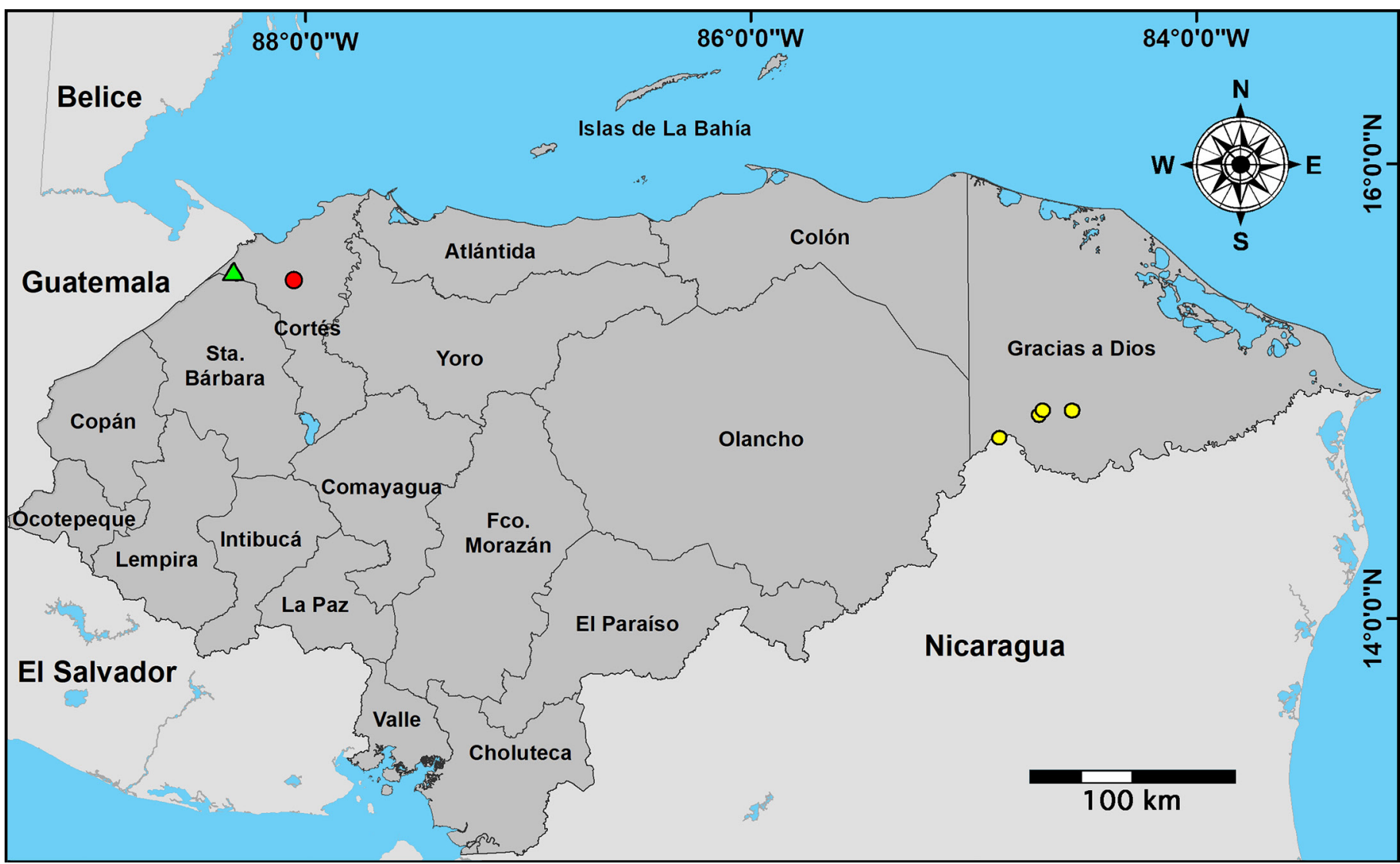

Fig. 1. Distribution of the Ringed Treeboa (Corallus annulatus) in Honduras. Yellow dots mark verified records; the red dot denotes the only valid locality listed in Smith and Acevedo (1997) and McCranie (2011); and the green triangle indicates the new locality where individuals of C. annulatus were found in the Sierra de Omoa, Department of Cortés, Honduras. 
and also can provide crucial information for their conservation. Although for decades this topic has received significant attention (Böhm et al. 2017; Roll et al. 2017), many aspects of the natural history of snakes remain relatively unknown (Rojas-Morales et al. 2019).

The Neotropical genus Corallus (Daudin 1803) is a monophyletic group of nine snake species with a collective distribution that extends from southeastern Guatemala in northern Central America into South America, with a limited range west of the Andes in Colombia and Ecuador; east of the Andes the genus is widespread in the Guianas, Amazonia, and the Atlantic forests of southeastern Brazil, as well as on continental and oceanic islands; the elevational distribution of members of this genus extends from sea level to about 1,000 $\mathrm{m}$ asl (Colson et al. 2013; Henderson 2015; Reynolds and Henderson 2018). These snakes are known to occur in habitats such as dry scrub, primary rainforest, secondary forest, agricultural areas, non-forested areas, and disturbed areas (Henderson and Pauers 2012; Pinto-Erazo and MedinaRangel 2018; Reynolds and Henderson 2018).

The Ringed Treeboa, Corallus annulatus (Cope 1876), is a moderately large arboreal snake with a disjunct distri- bution that extends along the Atlantic versant from eastern Guatemala to northwestern Colombia; it also occurs in southeastern Nicaragua and along the Pacific versant in central and southern Panama at low and moderate elevations, perhaps as high as 1,000 m (McCranie 2011; Reynolds and Henderson 2018). In Honduras, the distribution of $C$. annulatus is highly disjunct, as it has been recorded in two departments on opposite sides of the country (Santa Bárbara and Gracias a Dios), but see our comment below regarding Henderson (2015). Currently, this species is categorized as being of Least Concern (LC) on the IUCN Red List (Sunyer and Köhler 2016), based largely on its widespread distribution (McCranie 2011). Using IUCN Red List criteria, however, the Honduran Reptile Specialist Group (2019) evaluated the status of this species as Endangered, and using the Environmental Vulnerability Measure, Johnson et al. (2015) assigned it a medium vulnerability score $(E V S=11)$. Herein, we clarify the distribution of Corallus annulatus in northwestern Honduras, and also expand our knowledge of its habitat and natural history.

One of us (MRE) was notified that an unusual "boa" had been found at a cardamom farm located in Cerro La Estrella,

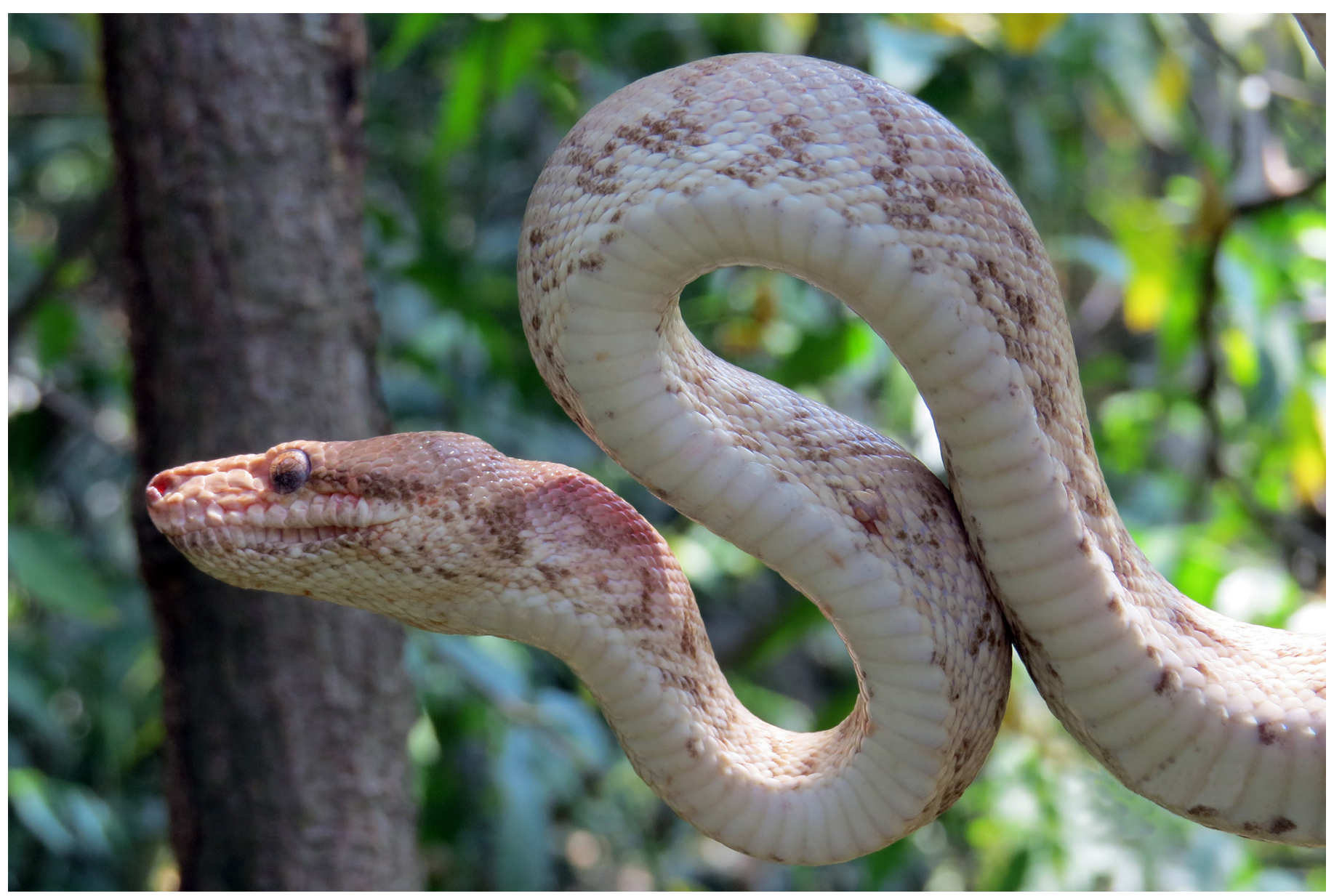

Fig. 2. An adult female Ringed Treeboa (Corallus annulatus) (UTADC-9628) from Cerro La Estrella, Sierra de Omoa, Municipalidad de Omoa, Department of Cortés, Honduras, with a total length of 1,750 mm. Photograph by Mario R. Espinal. 
Sierra de Omoa, Municipalidad de Omoa, Department of

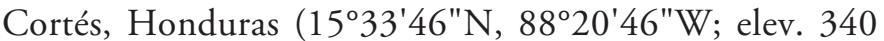
$\mathrm{m}$ asl) on 4 June 2018 (Fig. 1). The snake, an adult female Corallus annulatus, was photographed, measured, and later released. The photograph was deposited in the University of Texas at Arlington Digital Collection under number UTADC-9628 (Fig. 2). Fearing that his workers would kill the snake, the owner of the farm held the snake captive for a few days, and on 9 June 2018 the snake gave birth to 14 neonates (Fig. 3). Another individual (sex unknown) was found at the same locality on 17 August 2018 at 1000 h, and was photographed but not collected; the snake was identified by MRE, but the photograph was accidentally deleted from his cell phone. Both individuals were encountered in vegetation on the ground, which Holdridge (1967) described as Premontane Wet Forest (Fig. 4). The farm is located 68 $\mathrm{km}$ NE of Livingston, Departamento de Izabal, Guatemala, and $415 \mathrm{~km}$ SW of Bodega de Río Tawalpás, Departamento de Gracias a Dios, Honduras.

McCranie et al. (2006) and McCranie (2011) documented the following Honduran localities for Corallus annulatus: Bodega de Río Tawalpás $\left(14^{\circ} 56^{\prime} 00^{\prime} \mathrm{N}, 84^{\circ} 31^{\prime} 60^{\prime} \mathrm{W}\right)$,

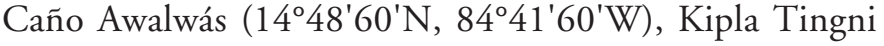
Kiamp (14 $\left.{ }^{\circ} 56^{\prime} 00^{\prime} \mathrm{N}, 84^{\circ} 40^{\prime} 00^{\prime} \mathrm{W}\right)$, and Urus Tingni Kiamp $\left(14^{\circ} 54^{\prime} 60^{\prime} \mathrm{N}, 84^{\circ} 41^{\prime} 00^{\prime} \mathrm{W}\right)$; all in the Department of Gracias a Dios. McCranie et al. (2006) also noted that individuals have been collected or seen at several localities in the Mosquitia. Using the information in McCranie (2011), the identification of the adult female Corallus annulatus (see above) was diagnosed by a combination of the following characters: loreals $=3 / 3$; supralabials $=14 / 14$; infralabials $=16 / 16$; snout-vent length $=1,550 \mathrm{~mm}$; and total length $=1,750 \mathrm{~mm}$.

Henderson (1993) was the first to report the occurrence of Corallus annulatus in Honduras, based on specimens (UTA-

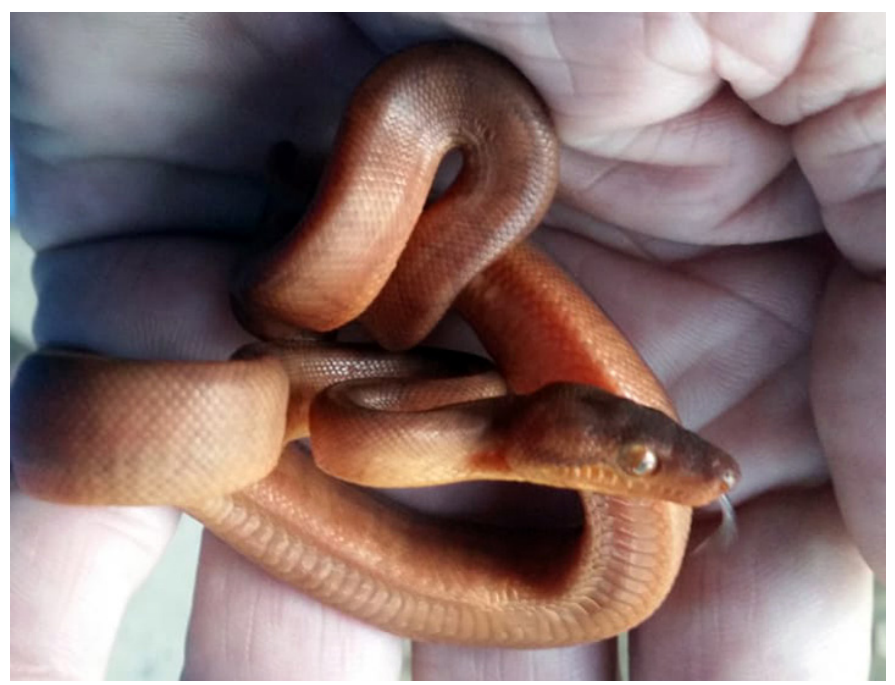

Fig. 3. A captive-born neonate from the adult female Ringed Treeboa (Corallus annulatus) (UTADC-9628). Photograph by Gerson Rivera.

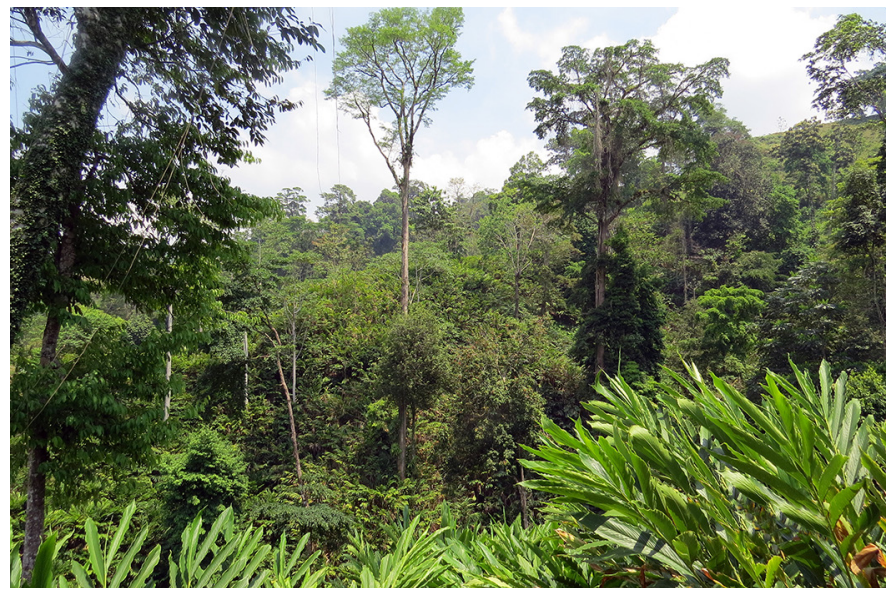

Fig. 4. Premontane wet forest in the foothills of the Sierra de Omoa, Municipalidad de Omoa, Department of Cortés, Honduras, where the adult female Ringed Treeboa (Corallus annulatus) (UTADC-9628) was found. Photograph by Mario R. Espinal.

R25356-70; an adult female and her 14 offspring) purportedly from Cofradía (Department of Cortés) in the Sierra de Omoa. Although Henderson (1993) expressed no doubt that the specimens came from Honduras, he questioned the locality because they were obtained from a commercial collector. For this reason, Wilson and McCranie (1994) did not include this taxon in their herpetofaunal list of Honduras. Subsequently, Smith and Acevedo (1997) reported this species from aldea (village) San Cristóbal, near Cofradía, in the Sierra de Omoa, Honduras, but speculated that the specimen might have come from elsewhere in the general region. Henderson et al. (2001) accepted the locality indicated in Smith and Acevedo (1997), since one of us (LWP) traced the specimen to its actual collector, and also noted that the provenance of the specimen was beyond doubt, a fact that was bolstered by the subsequent collection of this species in Guatemala (Smith and Acevedo 1997; Campbell 1998). The following year, McCranie et al. (2002) reported on a specimen collected in Rus Rus, in the Department of Gracias a Dios, but commented that it was unlikely that the specimens reported by Smith and Acevedo (1997) and Henderson et al. (2001) came from the locality they mentioned, as a locality with the same name exists in an adjacent department. McCranie (2011: 68) indicated that aldea de San Cristóbal is located adjacent to the Río Ulúa and lies in the department of Santa Bárbara, 35-airline km S of Cofradía, Cortés. Additionally, McCranie (2011) noted that the comment by Campbell (1998: 192) that this species is "known from the Sierra del Merendón [=Sierra de Omoa] in Honduras" was in error.

In an attempt to clarify the exact locality, McCranie (2011) apparently was unaware that topographical maps of the Department of Cortés show a village called aldea San Cristobal Merendón, which lies between cerro (hill) La Esperanza and the community of Cuyamel $\left(15^{\circ} 36^{\prime} 50.09^{\prime \prime} \mathrm{N}\right.$, 
$88^{\circ} 8^{\prime} 54.47 " \mathrm{~W} ; 306 \mathrm{~m}$ ); the village is located ca. 21.8 airline $\mathrm{km} \mathrm{N}$ of Cofradía, Cortés. This locality is 87 -airline $\mathrm{km} \mathrm{SE}$ of Izabal, Guatemala, the northernmost known locality for Corallus annulatus. McCranie (2011: 68) based his argument on a personal communication with one of us (MRE; who later realized the information he provided was incorrect), but ignored the fact that LWP had contacted the actual collector and verified the locality information. More recently, a photograph of $C$. annulatus from aldea San Carlos, Municipio de Omoa, Cortés, was published in Henderson (2015); the photographer provided us with additional information, including the name of the collector (Q. Dwyer, pers. comm.).

In summary and in view of the above information, we believe that the correct locality for the adult female collected in the mid-1980s should be considered as Sierra de Omoa (= Sierra de Merendón [15³1.06 $\left.\mathrm{N}, 88^{\circ} 04.10^{\prime} \mathrm{W}\right]$ ), in the Department of Cortés. Further, the photograph in Henderson (2015) and the additional information provided by the photographer, as well as the photographic voucher reported herein and the anecdotal information on the second individual that was photographed, should remove any doubt as to the provenance of the record for $C$. annulatus reported in Smith and Acevedo (1997) and Henderson et al. (2001). Accordingly, the statement made by McCranie (2011) regarding the information that appeared in Campbell (1998) is incorrect. The revision of this record leaves this species unrecorded from the department of Santa Bárbara.

The forests along the Sierra de Omoa are home to a large number of herpetofaunal species and also contain the highest degree of endemism in this part of the country. From a conservation perspective, Townsend (2006) noted that the Sierra de Omoa is an area in need of greater protection, and thus research like ours provides important information for helping to understand the biodiversity of these ecosystems.

\section{Acknowledgements}

We thank Daniela E. Medrano for providing editorial comments on an early version of the manuscript, Gregory Gabriel Pandelis for cataloguing the photographic vouchers into the University of Texas at Arlington Digital Collection, and Quetzal Dwyer, Manuel Paz, and Henry Quin for providing the information we requested. JMM acknowledges Emilce Rivera, Department Head (Carrera de Gestión Ecoturística, Sede Central, Universidad Técnica Nacional), and Daniel Tobias, Unit Coordinator (Ciencias Básicas, Sede Atenas, Universidad Técnica Nacional), for providing time and support to work on this paper.

\section{Literature Cited}

Böhm, M.R., Kemp, R. Williams, A.D. Davidson, A. Garcia, K.M. McMillan, H.R. Bramhall, and B. Collen. 2017. Rapoport's rule and determinants of species range size in snakes. Diversity and Distributions 23: 1472-1481. https://doi.org/10.1111/ddi.12632.

Campbell, J. 1998. Amphibians and Reptiles of Northern Guatemala, the Yucatán, and Belize. University of Oklahoma Press, Norman, Oklahoma, USA.

Colston, T.J., F.G. Grazziotin, D.B. Shepard, L.J. Vitt, G.R. Collie, R.W. Henderson, S.B. Hedges, S. Bonatto, H. Zaher, B.P. Noonan, and F.T. Burbrink. 2013. Molecular systematics and historical biogeography of tree boas (Corallus spp.). Molecular Phylogenetics and Evolution 66: 953-959. https://doi.org/10.1016/j.ympev.2012.11.027.

Henderson, R.W. 1993. Corallus annulatus (Cope). Catalogue of American Amphibians and Reptiles 573: 1-3.

Henderson, R.W. 2015. Natural History of Neotropical Treeboas (genus Corallus). Edition Chimaira, Frankfurt/Main, Germany.

Henderson, R.W., M. Höggren, W.W. Lamar, and L.W. Porras. 2001. Distribution and variation in the treeboa Corallus annulatus (Serpentes: Boidae). Studies on Neotropical Fauna and Environment 36: 39-47. DOI: 10.1076/snfe.36.1.39.8883.

Henderson, R.W. and M.J. Pauers. 2012. On the diets of Neotropical treeboas (Squamata: Boidae: Corallus). South American Journal of Herpetology 7: 172180. DOI: 10.2994/057.007.0207.

Holdridge, L.R. 1967. Life Zone Ecology. Tropical Science Center, San José, Costa Rica.

Johnson, J.D., V. Mata-Silva, and L.D. Wilson. 2015. A conservation reassessment of the Central American herpetofauna based on the EVS measure. Amphibian \& Reptile Conservation 9(2): 1-94 (e100).

McCranie, J.R. 2011. The Snakes of Honduras: Systematics, Distribution, and Conservation. Society for the Study of Amphibians and Reptiles. Contributions to Herpetology, Volume 26. Ithaca, New York, USA.

McCranie, J.R., K.E. Nicholson, and F.E. Castañeda. 2002. Preliminary results of herpetofaunal survey work in Rus Rus region, Honduras: a proposed biological reserve. Herpetological Bulletin 81: 22-29.

McCranie, J.R., J.H. Townsend, and L.D. Wilson. 2006. The Amphibians and Reptiles of the Honduran Mosquitia. Krieger Publishing Co., Malabar, Florida, USA.

Pincheira-Donoso, D., A.M. Bauer, S. Meiri, and P. Uetz. 2013. Global taxonomic diversity of living reptiles. PLoS One 8: e59741. https://doi.org/10.1371/journal.pone.0059741.

Pinto-Erazo, M.A. and G.F. Medina-Rangel. 2018. First record of Corallus blombergi (Rendahl \& Vestergren, 1941) (Serpentes, Boidae) from Colombia. Check List 14: 183-188. DOI: 10.15560/14.1.183.

Reynolds, R.G. and R.W. Henderson. 2018. Boas of the world (Superfamily Booidae): A checklist with systematic, taxonomic, and conservation assessments. Bulletin of the Museum of Comparative Zoology 162: 1-58. DOI: 10.3099/MCZ48.1.

Rojas-Morales, J.A., M. Marín-Martínez, and J.C. Zuluaga-Isaza. 2019. Rediscovery of the enigmatic forest racer snake, Dendrophidion boshelli Dunn, 1944 (Serpentes, Colubridae): actions for the conservation of a critically endangered species. Neotropical Biology and Conservation 14: 577-589. DOI: $10.3897 /$ neotropical.14.e39572.

Roll, U., A. Feldman, M. Novosolov, A. Allison, A.M. Bauer A.M., R. Bernard, M. Böhm, F. Castro-Herrera, L. Chirio, B. Collen, G.R. Colli, L. Dabool, I. Das, T.M. Doan, L.L. Grismer, M. Hoogmoed, Y. Itescu, F. Kraus, M. LeBreton, A. Lewin, M. Martins, E. Maza, D. Meirte, Z.T. Nagy, C. de C. Nogueira, O.S.G. Pauwels, D. Pincheira-Donoso, G.D. Powney, R. Sindaco, O.J.S. Tallowin, O. Torres-Carvajal, J-F. Trape, E. Vidan, P. Uetz, P. Wagner, Y. Wang, C.D.L. Orme, R. Grenyer, and S. Meiri. 2017. The global distribution of tetrapods reveals a need for targeted reptile conservation. Nature Ecology \& Evolution 1: 1677-1682. https://doi.org/10.1038/ s41559-017-0332-2.

Smith, R.N. and M.E. Acevedo. 1997. The northernmost distribution of Corallus annulatus (Boidae), with comments on its natural history. The Southwestern Naturalist 42: 347-349.

Sunyer, J. and G. Köhler. 2016. Corallus annulatus. The IUCN Red List of Threatened Species 2016: e.T203206A2762097. https://dx.doi.org/10.2305/ IUCN.UK.2016-3.RLTS.T203206A2762097.en.

Townsend, J.H. 2006. Inventory and conservation assessment of the herpetofauna of the Sierra de Omoa, Honduras, with a review of the Geophis (Squamata: Colubridae) of eastern nuclear Central America. Unpublished Ph.D. dissertation, University of Florida, Gainesville, Florida, USA.

Wilson, L.D. and J.R. McCranie. 1994. Second update on the list of amphibians and reptiles known from Honduras. Herpetological Review 25: 146-150. 